Elżbieta Pokorzyńska

Warszawa

\title{
Oprawa książki w XIX i pierwszej połowie XX wieku Technologia oprawy a elementy morfologiczne książki
}

Oprawa książki to efekt działań introligatora, nadających arkuszom papieru postać książki (kodeksu). Potocznie i intuicyjnie oprawę kojarzy się z okładką książki, zewnętrzną osłoną bloku książki. To zawężenie pojęcia tylko do oprawy trwałej (twardej), powoduje, że książkę w oprawie broszurowej niekiedy niesłuszne nazywa się „nieoprawną”.

Lepiej niż określenia „oprawa” i „oprawianie” sedno zagadnienia oddają dawne nazwy ,introligowanie” oraz „wiązanie” ksiąg. Słowo introligatorstwo istnieje tylko w języku polskim. Jego łaciński źródłosłów: „intro” - do wewnątrz, „ligare” - wiązać, wyraźnie wskazuje, iż istotą działania nie było nadanie książce zewnętrznej osłony, lecz połączenie w integralną całość osobnych elementów - kart. Toż samo spotykamy w archaicznym określeniu ,wiązanie ksiąg”, „wiązacze ksiąg” (compactores librorum $^{1}$ ) które dosłownie odpowiada określeniom angielskim (bookbinding), niemieckim (Buchbinder), francuskim (relier le livre), włoskim (legatura).

Łączeniem w całość długiego tekstu, nie mieszczącego się na jednej karcie zajmowali się introligatorzy już w starożytności; w wyniku zastosowanej metody - sklejania papirusowych arkuszy w długą wstęgę (następnie rolowaną w zwój) zyskali miano glutinatores (glutinatorów, sklejaczy). Kodeksowa forma księgi jest wynalazkiem czasów rzymskich. Wzorując się na używanych do podręcznych zapisków dyptychach lub poliptychach - wiązkach tabliczek woskowych, introligatorzy, miast skle-

${ }^{1}$ Compactor od compingo - razem spajać. W Stowniku polsko-tacińskim ks. A. Bielikowicza (Kraków 1866) znajdujemy także polskie określenie „księgowiąż”. 
jać karty ze sobą, zaczęli je przełamywać na pół, wkładać jedna w drugą i związywać w miejscu przełamania. $Z$ biegiem czasu wypracowano system łączenia większej ilości kart, zszywając ze sobą kilka takich zeszycików oraz dodając im zewnętrzną osłonę.

Introligatorstwo, służąc przez stulecia książce rękopiśmiennej, wydało ograniczoną liczbę bardzo wypracowanych i kosztownych dzieł sztuki zdobniczej. Także oprawy ksiąg użytkowych, aczkolwiek wykonywane ze skromniejszych materiałów, realizowano pieczołowicie i pracochłonnie. Introligatorstwo zyskało na rozmachu wraz z upowszechnieniem papieru i rewolucją drukarską, które wywołały lawinowy przyrost ilości ksiąg wymagających oprawy. Wprawdzie pierwsze drukowane księgi oprawiano jeszcze według tradycyjnych technologii, lecz szybko powstały i z czasem upowszechniły się techniki uproszczone i oszczędniejsze czasowo.

W wieku XIX forma książki daleko odeszła od swego pierwowzoru. Różniły ją gabaryty, ciężar, zastosowane materiały piśmienne, technologia umieszczenia w niej tekstu, wygląd zewnętrzny i forma zdobnicza. Jedyne co pozostało niezmienne, to owa metoda związania arkuszy w jednym boku (w grzbiecie) pozwalająca na swobodne odwracanie kart.

Sposób wykonania oprawy warunkuje fizyczną postać książki, w szczególności zewnętrzną, ale po części także i wewnętrzną. Morfologia książki zajmująca się opisem formy zwykle abstrahuje od procesów wykonawczych; wydaje się jednak zasadna próba uporządkowania i powiązania ze sobą tych aspektów.

\section{Prace przygotowawcze}

Prace początkowe, zwane przygotowawczymi, muszą być wykonane dla każdego rodzaju książki, nawet takiej, którą potocznie określa się jako nieoprawioną.

Pierwszą czynnością jest przygotowanie arkuszy. W dawniejszych wiekach, gdy stosowano do druku papier nie klejony (zwany też papierem wodnym), było nią zaklejenie (planirowanie) papieru. Polegało ono na zanurzaniu każdego arkusza w rzadkim roztworze kleju (kostnego, rybiego). Następnie arkusze suszono (podobnie jak w papierni) na sznurkach, a po wysuszeniu zbijano je bądź prasowano dla wygładzenia powierzchni.

Czynnością przygotowawczą mogło być wstępne przekrojenie zadrukowanych arkuszy. Było ono konieczne w przypadkach, gdy na każdym arkuszu papieru drukowano podwójnie (dwa egzemplarze tego samego 
arkusza wydawniczego); praktyka taka oszczędzała drukarzom pracy i była w XIX i na początku XX wieku dość popularna².

Kolejną czynnością było składanie arkuszy (zwane z niemiecka falcowaniem, a w dzisiejszej nomenklaturze poligraficznej - złamywaniem), w celu uzyskania z nich składek. Układy kolumn na arkuszu były zwyczajowo ustalone, po wielokrotnym złożeniu arkusza na pół, automatycznie strony powinny ułożyć się we właściwym porządku³. Falcowanie jest wykonywane nie tylko w przypadku książek, lecz także w wydawnictwach prasowych. Falcowania dokonywano ręcznie, na odpowiednio dużych stołach; składany na pół arkusz dociskano w miejscu złamania kostką introligatorską. Przy falcowaniu ręcznym osiągano wydajność około tysiąca załamań na godzinę, a że książkowy arkusz jest składany 3-4 razy, wykonywano w tym czasie około 200-300 składek $^{4}$.

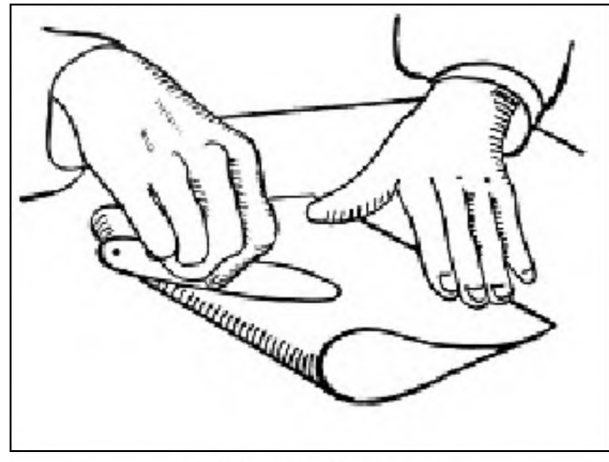

1. Falcowanie ręczne

Czynność tę wykonywali zwykle pracownicy niższych kategorii, uczniowie lub kobiety przyuczone do tej czynności. $\mathrm{W}$ zawodowych podręcznikach zwracano uwagę na równe, staranne falcowanie, tak by kolumny druku idealnie na siebie padały. Zadanie to było utrudnione w przypadku, gdy rozkład wydrukowanych kolumn nie mieścił się dokładnie na środku arkusza. Osoba falcująca musiała wówczas wyszukać w każdym arkuszu właściwe miejsce załamania, dopasowując paginy tak, aby padały na siebie w kolejnych kartkach.

Kolejna z czynności przygotowawczych to skompletowanie składek, zwane też zbieraniem. Prowadzi ono do otrzymania w jednym stosie wszystkich arkuszy książki we właściwej kolejności. Osoba wykonująca tę czynność układała stosy sfalcowanych arkuszy na dużym stole, a następnie, obchodząc go, zabierała z każdego po jednej składce i układała

${ }^{2}$ A. Semkowicz, Introligatorstwo z krótkim zarysem historii zdobnictwa opraw, Kraków 1948, s. 37-38.

${ }^{3}$ Rozkłady kolumn publikowały różne poradniki drukarskie, spotykamy je już wśród rycin ilustrujących zawód drukarski w Wielkiej Encyklopedii Francuskiej.

4 Uktad zbiorowy pracy dla przemystu poligraficznego w Polsce, Warszawa 1947, s. $55-57$. 
je w stos. Każdy kolejny komplet odwracano na przemian grzbietami. Pomocą w zachowaniu właściwej kolejności składek jest sygnatura - nadruk umieszczany u dołu pierwszej strony w każdym arkuszu, zawierający skrócony tytuł dzieła oraz kolejny numer arkusza. Ponadto w wieku XX wprowadzono dodatkowe oznakowania w formie małych czarnych pasków wydrukowanych na grzbiecikach składek. Ich układ jest schodkowy, tj. w każdym kolejnym arkuszu mieści się coraz niżej; jedno spojrzenie pozwala skontrolować kolejność składek w stosie. W przypadku, gdy układ kart i wkładek w książce nie był oczywisty, wydawca drukował dla introligatora wskazówki, w jakim porządku ma ułożyć karty ${ }^{5}$.

Obie wstępne czynności przygotowawcze w końcu XIX wieku uległy mechanizacji, do prac tych zastosowano falcerki oraz zbieraczki z taśmą transportującą. Maszyny zwiększały znacznie wydajność: falcerki nożowe osiągały prędkość 3000 taktów (złamań) na godzinę, zaś falcerki kieszeniowe nawet dwukrotnie więcej. W urządzenia mechaniczne zaopatrywały się duże zakłady, w mniejszych warsztatach, oprawiających niewielkie nakłady, jeszcze do dnia dzisiejszego, prace te bywają wykonywane ręcznie.

W technologii oprawy twardej do prac przygotowawczych należy przygotowanie wyklejki. Wyklejka (forzac, spolszczony z niemieckiego: Vorsatz), zwana też przedkładką lub podlepką, to złożona na pół kartka, zwykle z nieco grubszego niż książka papieru; przykleja się ją na wąskiej powierzchni tuż przy grzbiecie, do pierwszej i ostatniej składki. Wyklejka połączy blok książki z okładką, gdyż w końcowej fazie oprawy jej zewnętrzna karta zostanie naklejona na wewnętrzną powierzchnię okładki. Wyklejka stanowi także ochronę kart książki przed zabrudzeniem na czas trwania procesu oprawy. Wyklejki wydawnicze nieraz przygotowywano specjalnie dla konkretnej edycji, drukując na nich dekorację powiązaną z publikacją, tendencja ta wzmocniła się w czasach współczesnych.

${ }^{5}$ W książce K.W. Wójcickiego, Pisma Adama Mickiewicza, wydanie nowe, Warszawa 1858, znajduje się „Wiadomość dla introligatoró w: życiorys Mickiewicza powinien być zamieszczony przy I tomie na początku. S.H. Merzbach" (cyt. za: X Salon Bibliofilski Towarzystwa Przyjaciót Książki, Warszawa 1998, s. 27); „Wskazówki dla introligatora” czy to w postaci ulotki czy wydrukowane na odwrocie broszurowej okładki drukowała firma wydawnicza Trzaska, Evert i Michalski, zwłaszcza dla bogatych w tablice ilustracyjne i mapy wydawnictw wielotomowych (np. Wielka Historia Powszechna, Encyklopedia Staropolska) sprzedawanych w drodze prenumeraty. Podobny instruktaż znajduje się w wydawnictwie encyklopedycznym Świat $i \dot{Z} y c i e$, tu opis został wzbogacony o wskazówki technologiczne, co do sposobu zszycia i obróbki bloku, sformułowane zapewne przez Bonawenturę Lenarta, który był projektantem okładki do tej publikacji. 
W przypadku oprawy wtórnej do czynności przygotowawczych (zamiast falcowania i kompletowania) należy: usunięcie starej okładki, rozdzielenie bloku na pojedyncze składki, przeprowadzenie potrzebnych reperacji (tu miejsce na zabiegi konserwatorskie papieru), przygotowanie elementów specjalnych do włączenia do bloku (mapy, tablice, okładki broszurowe) przez doklejenie ich za pomocą pasków papierowych (tzw. falców) do składek. Wyklejki stosowane w oprawach ręcznych sporządzane są na różne sposoby. Najprostsze to złożone na pół kartki doklejone do skrajnych składek. W gotowej już książce wyklejka taka, po otwarciu okładki, przedstawia jednolitą powierzchnię, przełamaną tylko złamem grzbietowym.

W oprawach dawniejszych najpopularniejsza była wyklejka przeszywana. Wykonywano ją się z kartki złożonej na pół, nieco szerszej niż książka. W odległości kilku milimetrów od złożenia zaginano ją równolegle i nakładano na skrajne składki, a w procesie szycia przeszywano razem $\mathrm{z}$ nimi. W wyklejce tej wąski jej pasek widoczny jest pomiędzy pierwszą i drugą składką (od przodu i od końca). Czasami introligatorzy przyklejali tę zaginkę do składki z którą ją zszywali, czasem sklejali z obiema składkami, wówczas karty książki w tym miejscu nie dają się swobodnie odwracać („ciągną”).

W drugiej połowie XIX wieku upowszechniła się wyklejka przeszywana wzmacniana paskiem płótna lub mocniejszego papieru (tzw. scyzura). Niekiedy wzmacniający pasek podklejano pod wyklejkę, w gotowej książce był wówczas niewidoczny, wyczuwalne było tylko zgrubienie, wynikające z jego obecności. Często wyklejkę sporządzano z dwóch osobnych kartek, połączonych tym płóciennym paskiem. Przy otwarciu okładki jest on widoczny w przegubie książki. Wyklejkę tego rodzaju można też sporządzać w odmienny sposób: na czas szycia i oprawiania blok książki zaopatrzony jest tylko w jedną kartę wyklejki (tę luźną, która osłania blok książki), drugi człon - tzw. lustro jest dołączane dopiero podczas wyklejania wewnętrznej strony okładki, gdy oprawa jest już gotowa.

Innym rodzajem wyklejki zawijanej jest wyklejka podwójna, wykonana $\mathrm{z}$ dwóch rodzajów materiału. Wnętrze okładki wyścielone jest materiałem ozdobnym - wzorzystym papierem, tkaniną jedwabną itp. Luźna karta wyklejki, tzw. „fruwająca” jest zdublowana, tj. naklejona na kartę zwykłego papieru. W oprawach z początku XIX wieku spotykamy jeszcze jedną białą kartę: w sumie więc wyklejkę stanowią dwie karty zwykłego papieru i dwie ozdobne. Dublowanie materiału wyklejkowego 
miało na celu jego usztywnienie. Czynność ta, niezbędna w przypadku wyklejek jedwabnych, uzasadniona była także, gdy ozdobną wyklejkę sporządzano z barwnego papieru glansowanego bądź marmurkowego, gdyż papiery ręcznie barwione często miały zabrudzenia na odwrotnej stronie. Zdublowana karta miała jedną wadę: była znacznie grubsza i sztywniejsza niż inne karty w książce. Ponadto dość często obserwujemy pofalowanie oraz wyginanie się wyklejki, wynikające z różnej siły „ciągnięcia” obu materiałów.

Dodać tu należy, że wyklejka zawijana przeszywana, stosowana masowo w oprawach XIX-XX-wiecznych ma też swoje mankamenty. Głównym jest wypchnięcie skrajnych składek od grzbietu o tyle, ile zajmuje grubość wyklejki. Gdy introligator obcinał następnie książkę, skrajne składki stawały się nieco węższe. Przy ewentualnej reoprawie stanowi to problem: albo skrajne składki muszą pozostać węższe, albo trzeba wyrównać bok, przycinając książkę jeszcze głębiej. Dlatego też poszukiwano rozwiązań, które pozwoliłyby uniknąć niepożądanych efektów. Jednym $z$ nich było zastosowanie wyklejki wielokartkowej, stanowiącej samodzielną, dodatkową składkę. Wyklejka taka nosi dziś miano konserwatorskiej. Stosowana bywa także w oprawach artystycznych, gdzie stanowi „podkład” do dublury, tj. wyścielenia wnętrza oprawy skórą bądź innym cennym materiałem.

Na koniec prac przygotowawczych komplet składek wraz z wyklejkami ulega wstępnemu sprasowaniu.

\section{Łączenie składek}

Istotą oprawy jest, jak wykazano na wstępie, połączenie składek lub kart w jedną całość, zwaną blokiem lub wkładem książkowym ${ }^{6}$.

Łączenie składek następuje najczęściej w drodze ich zszycia. Tradycyjne, ręczne zszywanie książek wykonywano przy pomocy szywnicy, na-

\footnotetext{
${ }^{6}$ Powojenna poligrafia, na fali polonizacji i normalizacji słownictwa fachowego zarzuciła tradycyjne nazewnictwo i w miejsce nazwy blok książki wprowadziła wkład książkowy, por. I. Pietruczuk, H. Godlewski, W. Jędrych, Technika i technologia introligatorstwa przemystowego, Warszawa 1985; S. Magdzik, Introligatorstwo przemystowe, Warszawa 1988; Pojęcie „wkład” znalazło się także we Wspótczesnym polskim introligatorstwie i papiernictwie (Wrocław 1986), gdyż zespół autorów pochodził głównie ze środowiska poligraficznego. W tradycyjnym rzemiośle, konserwacji książki i w księgoznawstwie utrzymała się nazwa bloku książki, sporadycznie stosowane jest także określenie trzonu książki, por. J. Osięgłowski, Ochrona ksiązki bibliotecznej, Poznań 2003; L. Ogierman, Konserwatorska ochrona zabytkowego zbioru bibliotecznego Zakonu Paulinów na Jasnej Górze, Katowice 2001.
} 
zywanej też z niemiecka heftladą. Jest to rodzaj drewnianej konstrukcji, ustawianej na stole. Pomiędzy podstawą a oddaloną od niej o kilkadziesiąt centymetrów poziomą belką rozpinano i zamocowywano sznurki, rzemienie bądź tasiemki. Składki zszywano igłą i mocną nicią, przeszywając ich grzbiety i łącząc kolejne składki, zahaczając jednocześnie o sznury, które stawały się podstawą konstrukcji, utrzymującej w całości blok. Po zakończeniu szycia całego tomu odcinano nadmiar sznurka, pozostawiając kilkucentymetrowe końcówki, tzw. „wąsy”. Służyły one później do połączenia bloku książki z okładzinami.

W ręcznym szyciu książek stosowano kilka ściegów. Historyczny ścieg „na okrętkę”. stosowano wraz z dość grubymi ścięgnami sznurkowymi lub rzemiennymi. Technika ta stosowana była w oprawie organicznej, w której skórę okładkową naklejano bezpośrednio na grzbiet książki; w efekcie powstawały bardzo wyraziste zwięzy na grzbiecie tomu. Wraz z XVIII-wieczną modą na płaskie grzbiety zreformowano technikę szycia, wprowadzając tzw. „wyszywanie”. Nitka przeszywająca składki obejmowała sznurki konstrukcyjne, ale bez ich okrążania; zastosowanie cieńszych, rozplecionych sznurków niemalże zniwelowało grubość zwięzów. W wieku XIX poczyniono kolejny krok służący niwelacji zgrubień: na grzbietach składek nacinano rowki, w które wpuszczano sznurki.

Technika wyszywania składek miała pewną wadę: dość grube lniane nici introligatorskie powodowały znaczne pogrubienie („narastanie”) grzbietu w stosunku do grubości całego bloku. Remedium na tę niedogodność był ścieg „dwa za jeden”. Introligator przy jednym przebiegu nitki wzdłuż grzbietu przeszywał jednocześnie dwie składki, wkłuwając się przemiennie raz w jedną z nich, raz w drugą. Szycie przemienne stosowano już od XVI wieku nawet przy ściegu „na okrętkę"7; w książkach z XIX i początku dwudziestego wieku występuje niemal bez wyjątku. Efektem stosowania tego ściegu jest to, że w środku każdej składki widać dwa odcinki nici i dwa miejsca bez nitki - na tej wysokości nitkę znajdujemy w sąsiedniej składce (w przeciwieństwie do oprawy „wyszywanej”, w której nitka widoczna jest wewnątrz każdej składki na całej jej długości).

${ }^{7}$ B.C. Middleton, A History of English Craft Bookbinding Technique, London 1978, s. 20-24. 


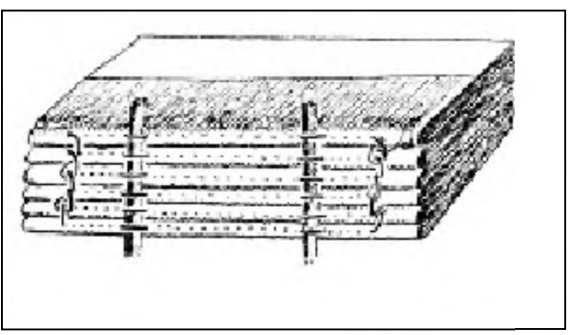

2. Blok książki „wyszywany”

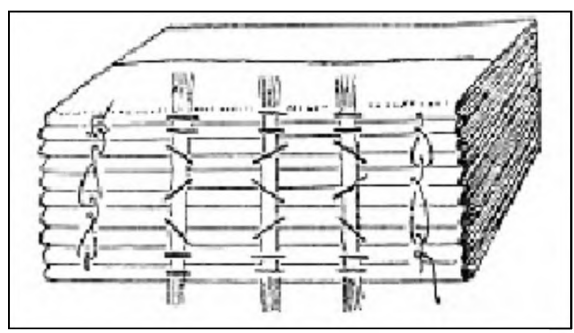

3. Blok uszyty ściegiem „dwa za jeden”

Oprócz szycia na zwięzy, introligatorstwo wypracowało szereg innych sposobów zszywania, czy też łączenia kart składających się na blok książki. Najstarszy z nich to średniowieczny sposób szycia ściegiem łańcuszkowym. Poszczególne składki przeszywano wraz z okładką, nici były widoczne na zewnątrz grzbietu książki. Nitka przeszywająca składkę była w określonych punktach grzbietu wyprowadzana na jego wierzch i zaczepiana o nitkę, którą zszyto poprzednią składkę. W późniejszych latach rzadko używano ten ścieg ${ }^{8}$; został on zastosowany w maszynach szyjących książki nićmi, w niciarkach, z tym że szycie następuje kilkoma nićmi naraz (z kilku szpul). Podobny rodzaj ściegu używano w łączeniu akt w poszyty, przyszywając partie papierów do grzbietu kartonowej teczki. Ścieg ten, nazywany przez archiwistów „szyciem prostym” polega na przeszywaniu każdej składki osobną nitką, związaną w jej wnętrzu ${ }^{9}$.

Odmienny jest sposób szycia „na sztych”, w którym karty łączono przeciągając nici, czy raczej sznurek, przez wywiercone uprzednio dwa lub więcej otworów, ulokowanych nie w przegubie, lecz w niewielkim oddaleniu od grzbietu. Sposób ten wykorzystywano w oprawie broszur i innych druków przeznaczonych do krótkotrwałego użytkowania, jak np. kalendarze ${ }^{10}$, miał też szczególne zastosowanie w archiwizacji dokumentów ${ }^{11}$. Luźne wiązanie ozdobnym sznurkiem spotykamy przy wyrobach galanteryjnych, zwłaszcza albumach i pamiętnikach (sztambuchach).

${ }^{8} \mathrm{~W}$ polskim dorobku introligatorskim spotykamy go w oprawie rękopisów Stefana Żeromskiego konserwowanych przez Bonawenturę Lenarta. Zachowane szczątki kart umieścił introligator w foliowych koszulkach, a te zszył razem z pergaminowymi okładkami oraz kościanymi płytkami, usztywniającymi grzbiety. Zob.: Autografy Stefana Żeromskiego w Muzeum Mickiewicza. Stefan Żeromski 1864-1964, [Warszawa 1964]; Tadeusz Tuszewski. Grafika, rysunek, konserwacja dziet sztuki, [Katalog wystawy], Warszawa 1987, s. 13.

${ }^{9}$ A. Moraczewski, Szycie akt. Wskazówki praktyczne, Warszawa 1935, s. 23-27.

${ }^{10}$ Kalendarz Warszawski na rok 1898 , toż na 1899 . Na sztych zszywano nawet te tomy, które uzyskiwały oprawę twardą płócienną.

11 A. Moraczewski, Szycie akt..., s. 31. 
Podobny rodzaj łączenia książek spotykamy w oprawie dalekowschodniej (chińskiej, japońskiej). W tej technice szycie następuje razem z okładkami; nić przechodzi przez otwory w bloku książki i jednocześnie oplata grzbiet.

Kolejny rodzaj szycia bez zwięzów to broszurowanie. Ma ono na celu prowizoryczne połączenie składek, z założeniem, że książka w późniejszym czasie zostanie trwalej oprawiona. W związku z tym ograniczano liczbę przeszyć każdej składki do jednego. Dla łatwiejszej rozbiórki przy ponownej oprawie, nie wiązano końcówek nici, sklejano je tylko podczas montowania bloku z broszurową okładką.

Specjalnym sposobem broszurowania było holendrowanie. Odbywało się ono przed fazą zbierania, tj. zszywano wszystkie egzemplarze pierwszej składki, następnie drugiej i kolejnych. Nitka nie łączyła składek ze sobą, lecz po przeszyciu była odcinana, z pozostawieniem długich końcówek. Skompletowane następnie książkowe wkłady montowano z okładką, sklejając równocześnie końcówki nici. Ten ścieg został zastosowany w maszynach szyjących termonićmi, tj. nićmi syntetycznymi; ich końcówki są rozgrzewane i trwale wtapiane w papier, co usuwa ryzyko wysunięcia i rozluźnienia bloku.

Niekiedy książki bywały szyte w sposób pośredni pomiędzy broszurowaniem a wyszywaniem, arkusze były trwale zszywane, lecz bez zastosowania ścięgien (sznurków czy tasiemek). Szycie takie stosuje się niekiedy przy oprawach broszurowych wykonywanych ręcznie (w małych zakładach o niedostatecznym wyposażeniu).

Osobnym zagadnieniem jest zszywanie druków jednoskładkowych. Następuje ono sposobem zeszytowym, tj. przez grzbiet składki i kartonowej okładki. Najprostszy sposób - jeden okrąg z nitki - jest dość niedogodny, znacznie korzystniejszy i polecany jest sposób „w ósemkę” w którym grzbiet przeszywany jest w kilku miejscach. W niektórych drukach bibliofilskich oraz w oprawie dyplomów w ogóle nie kaleczono papieru nakłuwaniem, lecz tylko przewiązywano karty razem z okładką.

Na koniec wspomnieć należy o szyciu książek składających się z pojedynczych kart (nie posiadających przegubu). Jest to sposób pośredni pomiędzy szyciem na zwięzy a szyciem ,na sztych”. Kilkukartkowe partie przyszywane są „na okrętkę”, tj. igła wbijana jest na sztorc w stosunku do kart, otacza ona zarazem konstrukcyjne sznurki, nić łączy także kolejne partie między sobą.

Z kolei szycie drutem odbywa się na dwa sposoby: albo blokowo - na sztorc, albo zeszytowo - przez grzbiet składki. Każdy z tych sposobów 
ma swoje ograniczenia: książki zszyte na sztorc trudno się otwierają, następuje wyłamanie kart i niszczenie książki. Tym niemniej, dzięki swej szybkości i niskiemu kosztowi szycie blokowe wykorzystywane było powszechnie w oprawianiu prac dyplomowych, druków urzędowych, a w trudnych latach tuż po II wojnie światowej - także w masowej oprawie broszurowej książek. Szycie bardzo grubych bloków dokonywane jest bez zaginania końcówek metalowych klamer, a blok przeszywany jest $\mathrm{z}$ obu stron (np. w bloczkach biletów). Z kolei szycie grzbietowe pozwala jedynie na łączenie pojedynczych zeszytów lub cienkich broszurek jednoskładkowych ${ }^{12}$. W tym rodzaju łączenia możliwe jest szycie z zewnątrz - wówczas końcówki zszywek znajdują się wewnątrz zeszytu, lub od środka - wówczas zagięcia znajdują się na grzbiecie.

Łącząc grzbietowe szycie drutem z mocowaniem kolejnych składek do taśmy płóciennej uzyskano dogodny sposób maszynowego szycia książek. Maszyny, zwane zszywarkami wielogłówkowymi przeszywały każdą składkę od wewnątrz kilkoma klamrami. Końcówki metalowych klamerek przechodziły także przez przyłożony do grzbiecików składek pas płótna lub merli introligatorskiej i dopiero na nim były zaginane. Technologia ta była stosowana masowo od lat 90 . XIX do połowy XX wieku. W książkach tak uszytych widoczne są metalowe zszywki w środku każdej składki ${ }^{13}$.

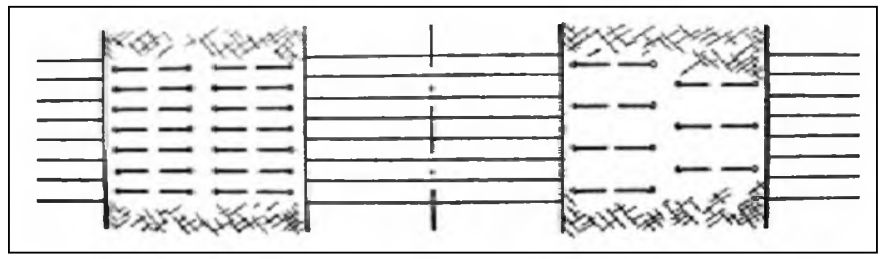

4. Szycie drutem przez merlę podwójne i z przesuwaną zszywką.

Kolejnym sposobem łączenia bloków książek jest tzw. metoda bezszyciowa. Najczęściej polega ona na sklejeniu grzbietu książki. Klejenie ma największe zastosowanie wówczas, gdy blok książki składa się z pojedynczych kartek, a klej dotrze do każdej z nich. W przypadku oprawy nakładowej ścina się grzbieciki składek, dla uzyskania pojedynczych kart. Czynność ta uniemożliwia zszycie książki przy ponownej oprawie.

${ }^{12} \mathrm{~W}$ praktyce szycie zeszytowe stosuje się co najwyżej do broszur 48-kartkowych, tj. 3-arkuszowych, z tym że arkusze nakładane są nie w stos, lecz otwarte - jeden w drugi.

${ }^{13} \mathrm{~W}$ maszynach wielogłówkowych używano cienkiego drutu, a dla uniknięcia zgrubienia grzbietu w miejscu zszywania pozycja zszywki w każdej kolejnej składce była inna. 
Łączenie klejowe stosowano także do druków ze składkami dwukartkowymi. O ile miała to być oprawa docelowa, grzbiety nacinano dla wzmocnienia połączenia. Oprawę tego rodzaju stosowano do druków akcydensowych, o jednorazowym przeznaczeniu ${ }^{14}$. Prowizoryczne łączenie klejowe, bez zszywania broszurowego, stosowano dla książek, które winny być oprawione natychmiast po zakupie. Nie obcinano ich, by nie doszło do pogubienia kart. Zdarzało się jednak, iż nabywca nie oddał takiej książki do oprawy, a tylko samodzielnie rozciął karty, by móc ją użytkować; broszury w tej postaci, z niezszytymi kartkami zachowały się do dnia dzisiejszego.

Łączenie klejowe wykonane z użyciem tradycyjnych klejów było nietrwałe. Klej pękał przy próbach silniejszego rozwarcia grzbietu. Lepsze efekty uzyskano przy zastosowaniu elastycznych klejów emulsyjnych (1925 rok), technologia łączenia klejowego od tego momentu bardzo się upowszechniła. Sklejanie grzbietu jest polecane dla notesów, bloków lub wydawnictw, z których przewiduje się wyrywanie kart.

Dla wzmocnienia sklejenia wykonuje się różne zabiegi wzmacniające połączenie. Jednym z nich jest przegięcie stosu kart, by nieco się rozchyliły, a klej wniknął w głąb grzbietu, inną zmechacenie grzbietu przed sklejeniem. W tym celu w oprawie maszynowej dokonuje się frezowania, a w oprawie ręcznej - nacięcia grzbietu. Stąd wykształciła się technika łączenia „na jaskółczy ogon”, polegająca na dość głębokim nadpiłowaniu rowków w grzbiecie i wpuszczeniu weń sznurków ${ }^{15}$. Sznurki w połączeniu ze spoiną klejową dość skutecznie utrzymują blok książki, a ich końcówki służą do połączenia z okładką, podobnie jak wąsy konstrukcyjnych sznurków przy szyciu nićmi. Jedynym mankamentem łączenia „na jaskółczy ogon" jest niemożność pełnego otwarcia książki.

Inną próbą wzmocnienia łączenia klejowego jest naklejenie na grzbiet mocnego i elastycznego materiału. W praktyce introligatorskiej stosowano płótno, a w introligatorstwie przemysłowym gazę introligatorską lub karbowany papier. Tak sklejone bloki zaopatrywano w twarde okładki. Połączenie klejowe nie zawsze jest trwałe, często książki pękają w trakcie użytkowania, a kartki wysypują się.

Obok omówionych podstawowych metod łączenia bloków książek, $\mathrm{w}$ introligatorstwie stosuje się metody zwane specjalnymi. Należy do

${ }^{14} \mathrm{~W}$ ten sposób wydrukowano i oprawiono Zdanie sprawy $z$ działań Warszawskiego Towarzystwa Dobroczynności za rok 1855, Warszawa 1855.

15 Nazwa pochodzi stąd, iż preferuje się podwójne, rozwidlone nacięcia, w które wchodzą dwa sznurki; w przekroju przypominają one schemat ogona jaskółki, stosowany w różnych sztukach, rzemiosłach i architekturze. 
nich łączenie za pomocą metalowych nitów bądź śrub, często o dekoracyjnej formie. Łączenie następuje, podobnie jak w szyciu "na sztorc" przez wywiercone uprzednio otwory. Lączenie nitami stosowano głównie w galanterii bądź w oprawach luksusowych, okazjonalnych; sporadycznie w wydawnictwach książkowych, głównie wówczas, gdy przewidywano dołączanie kolejnych kart do wydanego wcześniej tomu ${ }^{16}$.

Podobny charakter mają łączenia

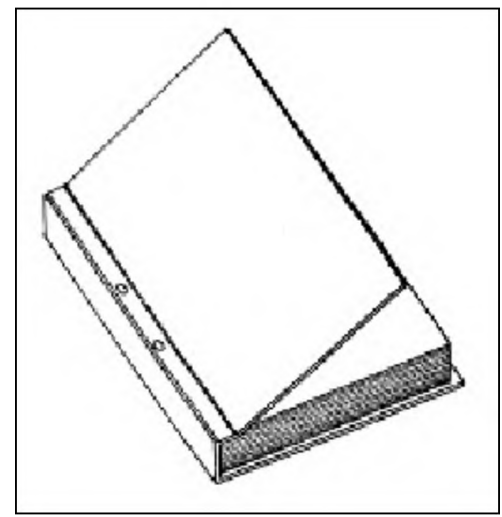

5. Oprawa łączona nitami na sztorc kart przy pomocy różnego rodzaju spiral, kółek lub tzw. „grzebieni” przewlekanych przez specjalnie nacięte otwory, czy wreszcie specjalnych konstrukcji, zbliżonych do zacisków segregatorowych.

$\mathrm{Na}$ koniec wspomnieć należy o najbardziej prymitywnej metodzie, jaką jest zbijanie gwoździami. Stosowano je głównie dla bloków o szczególnie dużej objętości, gdy zszywanie drutem okazywało się niemożliwe bądź nie dość wytrzymałe; technikę tę stosowano także w archiwizowaniu dokumentów ${ }^{17}$.

\section{Obróbka bloku książki}

Blok książki jest prostopadłościanem wizualnie przypominającym spłaszczony kloc drewna lub cegłę, z tym że jeden jego bok - ten, na którym znajduje się połączenie (wiązanie) różni się wyglądem, a przede wszystkim funkcją od trzech pozostałych. Bok grzbietowy w trakcie dalszej obróbki podlega wzmocnieniu, podczas gdy pozostałe zostają obcięte.

Dalsza obróbka grzbietu to przede wszystkim jego zaklejenie (dotyczy to wyłącznie bloków szytych). Klejowa spoina czyni grzbiet zwartym, składki ponadto sklejają się ze sobą.

Kolejna faza to wyokrąglenie grzbietu. Uzyskiwane jest poprzez uderzanie w skrajne składki bloku, które lekko wysuwają się ku przodowi. Tradycyjne wyokrąglanie dokonywało się przy użyciu młotka, do pracy tej służy specjalna maszyna zwana obijaczką, której zasadniczym

${ }^{16}$ Ten sposób oprawy zastosowano m.in. do słownika osobowego: S. Łoza, Czy wiesz kto to jest? Warszawa 1938 oraz książki telefonicznej Spis abonentów sieci telefonicznej m.st. Warszawy 1939/40.

${ }^{17}$ A. Moraczewski, Szycie akt..., s. 30. 
elementem jest metalowa, lekko wyokrąglona belka, poruszająca się ruchem kolebkowym. W trakcie procesu wyokragglania naciska ona skrajne składki na całej ich długości. Wyokrąglenie grzbietu możliwe jest tylko w książkach zszytych nićmi ręcznie lub maszynowo oraz w książkach uszytych drutem na zszywarce wielogłówkowej (przyszywającej arkusze zeszytowo do taśmy na grzbiecie). Wyokrąglenie grzbietu bywa zróżnicowane, zależy nie tylko od zamysłu introligatora, lecz także np. od grubości zastosowanych nici: grzbiety zbyt pogrubione szyciem (za mocno „naszyte”) wyokrąglają się automatycznie. XX-wieczna moda we wzornictwie książkowym wytworzyła oprawy twarde z grzbietem prostym, nie wyokrąglonym. Także broszury mają grzbiet prosty.

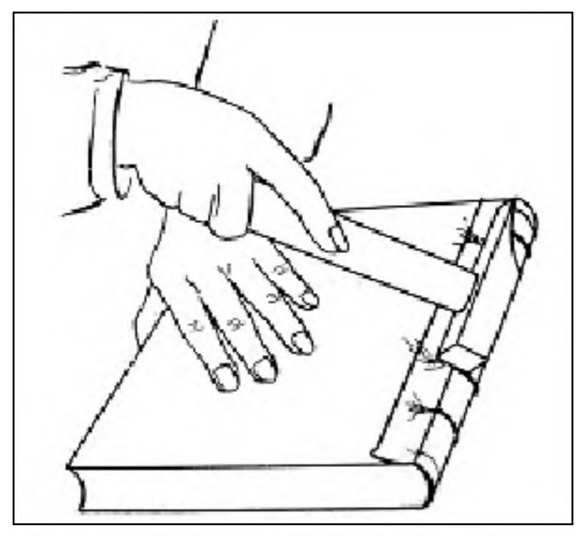

6. Ręczne wyokrąglanie grzbietu

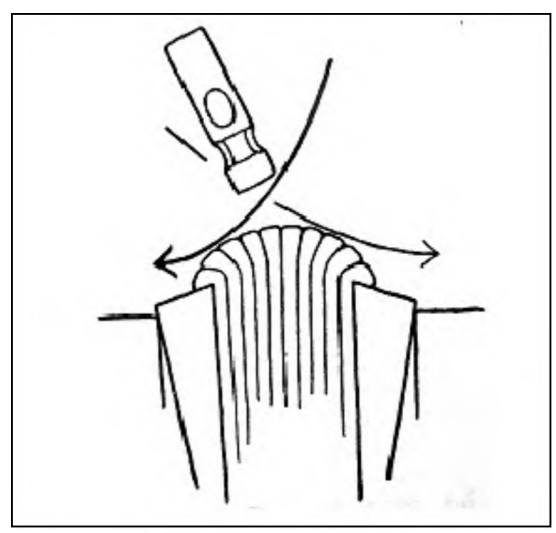

7. Nabijanie oporka

Oprawy szczególnie starannie wykonane mają grzbiet zaoporkowany. Oporkowanie polega na wygięciu grzbiecików składek, tak, że w przekroju grzbiet uzyskuje kształt grzybka. Dokonuje się poprzez obijanie grzbietu małym młotkiem, podczas gdy książka zaciśnięta jest w prasie belkowej, z której wystaje tylko obrabiany grzbiet. Oporkowanie stosowano także w XIX-wiecznych oprawach wydawniczych, w oprawie angielskiej utrzymało się po dzień dzisiejszy. Dokonywano go przy użyciu maszyny, która poszerzała i spłaszczała nieco grzbiet przy użyciu karbowanej wyokrąglonej belki uderzającej w grzbiet.

Zarówno podczas wyokrąglania, jak i oporkowania szerokość grzbietu powiększa się, końcówki zwięzów lub taśm wsuwają się nieco pod nici. Wyprofilowany grzbiet podlega ponownemu zaklejeniu, tym razem wraz ze zwięzami. 
Dla dodatkowego wzmocnienia grzbietu naklejano nań różnego rodzaju materiały. Na skrajach grzbietu mieszczą się kapitałki. Kapitałka jest reliktem średniowiecznego szycia książek, gdy na końcach grzbietu umieszczano skrajne zwięzy. Te konstrukcyjne sznury bądź rzemienie, wystające spod okładki, oplatano następnie dla dekoracji kolorowymi nitkami lub cienkimi rzemyczkami. Gdy jednak zaczęto obcinać boki książek po uszyciu, zaniechano wykonywania skrajnych zwięzów, a przejście nici $\mathrm{z}$ jednej składki do drugiej przesunięto nieco w głąb grzbietu. Natomiast na końcach grzbietu zaczęto haftować specjalne, ozdobne wypustki, podkładając w ich środek sznureczek lub rzemyk. Taka kapitałka była przyszyta do grzbietu ksiązki. Z czasem zredukowano ją do obdzierganej osobno tasiemki, którą przyklejano do skrajów grzbietu. W miejsce dzierganej kapitałki na początku wieku XIX zaczęto stosować kapitałkę sklejoną z jedwabiu, w której środek wklejono sznurek; w późniejszych latach upowszechniła się kapitałka sklejona z cienkiego płócienka (perkalu), zwykle w drobne biało-czerwone bądź biało-niebieskie prążki. Od końca wieku XIX kapitałki są dostarczane przez fabryki włókiennicze. Rzadziej spotkać można kapitałkę sklejoną z cienkiej skórki. W niektórych książkach pod kapitałkę wklejano tasiemkę służącą za zakładkę.

Ostatecznym wzmocnieniem było naklejenie paska jakiegoś materiału na grzbiet. W oprawach zwykłych był to papier makulaturowy, w oprawach starannych na grzbiet nalepiano nawet kilka warstw materiału, np. perkal, mocny papier, a na wierzch pasek skóry, który pozwalał na idealne zniwelowanie wypukłości szwów i kapitałki (poprzez szlifowanie wierzchu papierem ściernym). Materiał naklejony na grzbiet miał także za zadanie izolację warstwy klejowej od grzbietu okładki.

Nieco inaczej przebiega obróbka grzbietu w oprawie $\mathrm{z}$ wypukłymi zwięzami. Materiał wzmacniający był naklejany jedynie na przestrzenie grzbietu pomiędzy zwięzami. Zwięzy konstrukcyjne, o ile są bardzo grube, pozostają w swym naturalnym stanie, natomiast zwięzy zbyt cienkie pogrubiano przez naklejenie paseczków tektury lub twardej skóry, tak by później garbiki uwypukliły się na powierzchni grzbietu.

Z kolei obróbka pozostałych trzech brzegów bloku książkowego polega na ich obcięciu. Obcięcie daje w efekcie wyrównanie brzegów, przede wszystkim jednak powoduje rozdzielenie kart książki, umożliwiając ich odwracanie. W dawnych czasach obcinania dokonywano przy użyciu hebla introligatorskiego lub okrągłego noża. Blok książki ściskano w prasie belkowej, z której wystawał tylko skraj, przeznaczony do ob- 
cięcia. Proste i precyzyjne wymiarowo obcięcie było w tych warunkach bardzo trudne. Niezmiernie ułatwiła i przyspieszyła pracę maszyna do obcinania - gilotyna, zwana też krajarką, która posiada ograniczniki, zarówno dla utrzymania prostopadłych i równoległych boków, jak też pozwalająca wykonywać wielokrotne cięcie według tego samego wymiaru.

Nie zawsze obcięcie ma miejsce w oprawie introligatorskiej. Niektóre broszury ukazywały się w sprzedaży nieobcięte. Czasami pomija się obcinanie książki w procesie ponownej oprawy lub oprawy konserwatorskiej, tak by zachować oryginalne, zdobione brzegi kart lub by nie zmniejszać formatu książki. Nadmierne obcinanie marginesów było jednym z najczęściej wytykanych introligatorom błędów ${ }^{18}$. Wytyczne dla oprawy bibliofilskiej przewidywały nie obcinanie bloku książki po zeszyciu, gdy zaś zachodziła konieczność rozcięcia lub wyrównania kart - obcięcie pojedynczo kart na nożycach introligatorskich ${ }^{19}$.

Obcięte boki często były zdobione. Najszlachetniejszą metodą zdobienia brzegów kart było złocenie. Wykonywano je na zimno, przy użyciu płatków złota, na podkładzie z glinki bolusowej, stosując białko jaja kurzego jako środek wiążący ${ }^{20}$. Zamiast złota używano także innych metali, zwłaszcza srebra; srebrna powłoka jednak z czasem ciemniała.

Inną tradycyjną metodą barwienia było malowanie czerwoną farbą (minią uzyskiwaną z ołowiu lub farbą jasnoczerwoną uzyskiwaną z mosiądzu), na przełomie XVIII/XIX wieku także farbą żółtą. W drugiej połowie wieku XIX farby ziemne zastąpiono otrzymywanymi chemicznie barwnikami anilinowymi ${ }^{21}$, które niestety wsiąkały w głąb papieru, tworząc zacieki na marginesach kart. W wieku XX praktykowano także bar-

18 L. Gocel, Przypadki jej królewskiej mości książki, s. 319-320: „Ale mamy też setki introligatorów, którzy najczęściej dopuszczają się dwóch przestępstw w stosunku do książki. Pierwsze - to daleko posunięte obcinanie jej marginesów. Często zdarza się widzieć zarówno w starodrukach, jak i książkach wspólczesnych obcięte brzegi z boku - tuż przy ostatniej literce, a czasem nawet tej literki zabraknie, a jeśli chodzi o obcięcie u dołu, to zapał domorosłego introligatora posuwa go do zniszczenia całego nawet ostatniego wiersza. Dlaczego to robią? Odpowiedź prosta: im mniejsza przestrzeń książki, tym mniej wyjdzie materiału, a więc zarobek będzie większy! A przecież do estetycznego wyglądu książki, a nawet - powiedziałbym - do jej uroku potrzebny jest duży, jak największy margines. Dziś nawet nowe cenne książki wcale nie są obcinane."

${ }^{19} \mathrm{~W}$ ten sposób została wykonana oprawa wydawnicza publikacji: B. Lenart, Konserwacja ksiązki zabytkowej i jej oprawy, Wilno 1926; tenże, Piękna ksiązka jako zespót czynników materialnych papieru, czcionek, ilustracji świattokowych, druku i opraw, Wilno 1928.

${ }^{20} \mathrm{Na}$ początku wieku XX stosowano także proszek złotniczy wiążący złoto, zob. Stemplowanie złotem. „Wiadomości Graficzne”, 1909, nr 40, s. 6.

${ }^{21}$ Barwniki anilinowe wynaleziono ok. 1870 roku, zob. B.C. Middleton, A History of English Craft..., s. 90. 
wienie przez wcieranie sproszkowanego grafitu. Brzegi tak zabarwione są niemal czarne, z metalicznym połyskiem.

Niezwykle popularne było w XIX wieku wzorzyste barwienie brzegów kart. Najprostszy sposób polegał na nakrapianiu jedną lub kilkoma farbami. Aby uzyskać nierównomierny, cętkowany deseń sypano na brzeg książki pokruszoną kredę. Część napryskiwanej farby osiadała na niej; później, po jej usunięciu, pozostawały w tym miejscu niezabarwione cętki.

Do trudniejszych i wysoce cenionych umiejętności należało marmoryzowanie brzegów. Barwienie boków książek odbywało się podobnie, jak wykonywanie papierów marmurkowych karagenowych. Na powierzchnię rzadkiego roztworu kleistego (gumy traganckiej lub karagenu) nakrapiano rozrobione z żółcią wołową farby. Formowano z nich wzór, rozciągając barwne plamy igłą, sztyftem lub tzw. „grzebieniem” (listewka z nabitym rzędem igieł). Brzegi książki przykładano do powierzchni pływających farb, które przenosiły się na nie, tworząc barwne, fantazyjne wzory. Spotykamy przykłady opraw, w których wyklejki z papieru marmurkowego mają identyczny wzór i barwy jak brzegi wkładu książki.

Dodatkowe zdobienie wykonywano techniką cyzelowania (wybijania wklęsłych wzorków metalową puncą), tworząc na złoconych najczęściej brzegach, geometryczne lub arabeskowe wzory. Zupełnie wyjątkowo malowano na brzegach kart obrazki (,fore-edge paintings”), co było umiejętnością stricte rysunkową, realizowaną na ściśniętym w prasie brzegu książki. Czasem łączono w jednej pracy kilka technik, np. złocenie, malowanie, cyzelowanie, lakierowanie (zmiana odcienia złota). Z mistrzów warszawskich umiejętnościami takimi mogli się poszczycić Franciszek Joachim Radziszewski i jego syn Stefan ${ }^{22}$. Ten sam warsztat wypracował także inny sposób fantazyjnego barwienia brzegów w nieregularne plamy i wzory (poprzez malowanie, wcieranie farb, spryskiwanie z efektem ściekania $\mathrm{i}$ in.).

\section{Konstrukcja łączenia bloku z okładką}

Konstrukcja oprawy to sposób połączenia okładki z blokiem książki. Współczesna terminologia poligraficzna wyodrębnia, ze względu na konstrukcję, dwa rodzaje opraw: proste i złożone. Oprawami prostymi określa te, w których połączenie następuje w obrębie grzbietu, rozumie-

${ }^{22}$ Przykłady takich zdobień na oprawach: Tomasz à Kempis, O naśladowaniu Chrystusa, Warszawa-Kraków 1923, BN I.1.984.203 A Cim.; Ryszard de Bury, Philobiblion, Lwów 1921, własność prywatna; A. Mickiewicz, Pan Tadeusz, Warszawa 1934, własność prywatna; zob. też. W. Łysiak, Patriotyczne empireum bibliofilstwa... Warszawa 2004, t. 1, s. 48. 
jąc przez to broszury, oprawami zaś złożonymi nazywa te, które łączą trzon książki z okładką przez wyklejkę - oprawy twarde (ew. półtwarde).

Ta uproszczona klasyfikacja obejmuje jedynie oprawy wykonywane przez współczesny przemysł poligraficzny (też nie wszystkie) i nie odpowiada potrzebom opisu opraw historycznych, ani też współczesnych opraw artystycznych czy eksperymentalnych.

Oprawy broszurowe, sklasyfikowane tu jako oprawy proste, posiadają okładki wykonane z jednego arkusza kartonu lub papieru. Najprostszy, a zarazem najczęstszy sposób ich połączenia z blokiem książki polega na przyklejeniu kartonowej okładki do grzbietu książki lub też przeszyciu jednoskładkowego wkładu książkowego razem z okładką.

Najoszczędniejszym wariantem oprawy jest oklejenie samego tylko grzbietu papierową (rzadziej płócienną) lamówką. W wieku XIX oprawę tego rodzaju nazywano „półpapierkami”"23; dziś taką obróbkę stosuje się często dla nadbitek autorskich.

Jeszcze innym rodzajem broszury jest oprawa kartonowa z płócienną lamówką. Blok książki zostaje zszyty blokowo (,na sztorc”) razem z kartonowymi okładkami, z tym że okładka przednia i tylna stanowią osobne użytki. Połączenie następuje zwykle za pomocą metalowych zszywek, choć możliwe jest także zszycie nićmi. Płócienny pasek stanowi estetyczne wykończenie oprawy, zasłaniając grzbiet książki oraz elementy konstrukcyjne.

Wśród broszur spotkać można także przypadki, że blok książki w ogóle nie został złączony z kartonową okładką, a jedynie w nią włożony.

Na przełomie XVIII/XIX wieku szereg książek otrzymywało oprawę ,alla rustica”. Z technologicznego punktu widzenia oprawa ,alla rustica" jest skrzyżowaniem oprawy miękkiej broszurowej z oprawą trwałą, docelową. Blok książki zostaje zaopatrzony w wyklejki (1- lub 2-kartkowe) i trwale zszyty, a grzbiet zaklejony. Tak przygotowany wkład książki zostaje oklejony arkuszem mocnego papieru, tj. sklejeniu podlega powierzchnia obu wyklejek oraz grzbiet. Obserwacja zachowanych egzemplarzy wskazuje, że oprawy takie rzadko obcinano.

Oprawa „alla rustica” była dość popularna w pierwszych dekadach XIX-wieku, w drugiej połowie tego stulecia powróciła jako oprawa brulionów, notesów czy kalendarzy, $\mathrm{z}$ tym że stosowany na okładki papier zastąpiono płótnem, a w wieku XX - sztucznymi tworzywami skóropodobnymi. Wykonywano także oprawy rustykalne z miękkiej skóry lub zamszu, w tym oprawy wydawnicze o charakterze bibliofilskim.

${ }^{23}$ Zob. cenniki introligatorskie: Warszawa, AGAD, Komisja Rządowa Przychodów i Skarbu 1420. 
Konstrukcja dawnych opraw twardych opiera się na połączeniu bloku książki z okładką przede wszystkim poprzez końcówki konstrukcyjnych sznurków (tzw. wąsów), tasiemek czy rzemieni. W tradycyjnych oprawach średniowiecznych i renesansowych, gdy okładziny wykonywano z drewnianych desek, połączenie polegało na przewleczeniu każdego ze sznurków przez dwa otwory, wywiercone w desce a na koniec zaklinowaniu ich drewnianymi kołeczkami. Gdy deski zastąpiono tekturą, nadal stosowano tradycyjne przewlekanie sznurków (także pasków pergaminowych bądź tasiemek) przez otwory w tekturze, z tym że ich końcówki nie były kołkowane, lecz przyklejane (oprawa francuska, tzw. Franzband).

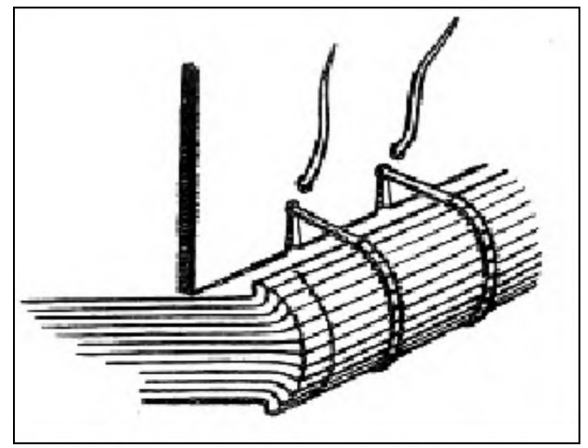

8. Konstrukcja oprawy francuskiej

Jednym $\mathrm{z}$ wariantów technologicznych było naklejanie końcówek sznurków na wierzch tektur zamiast ich przewlekania, ta drobna cecha tworzy odrębny typ, zwany oprawą niemiecką (Deutschband $)^{24}$. Dodatkowym elementem wzmacniającym mógł być płócienny pasek naklejony na grzbiet; jego końce wystające na boki, tzw. skrzydełka nalepiano, wraz z wąsami, na tekturki okładkowe.

Tradycyjny przebieg wykonywania oprawy wyglądał zatem tak, że do końców sznurków przymocowywano deski lub tekturki, a dopiero potem całość oklejano materiałem pokryciowym (skórą, pergaminem, płótnem czy papierem). W partii grzbietowej materiał

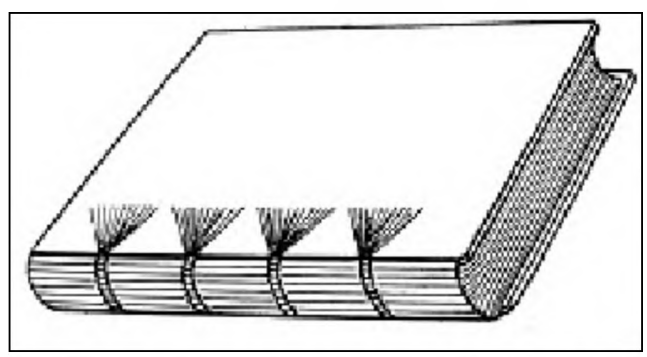

9. Konstrukcja oprawy niemieckiej naklejano bezpośrednio na grzbiet bloku (grzbiet zwarty), zatem jeśli książka miała na grzbiecie wypukłe zwięzy, uwypuklały się one także na zewnątrz oprawy. Oprawę wykonaną w ten sposób określa się mianem oprawy organicznej lub konstrukcyjnej.

${ }^{24}$ Co ciekawe, ta metoda określona została przez polskiego autora XIX-wiecznego metodą angielską. Zob. Oprawa książek na sposób angielski poprawny, „Piast”, 1829, nr 1, s. 113-114; Zob. też uwagi na temat niejednolitości nomenklatury introligatorskiej: http://vuscor.blogspot.com/2008/08/bradel-etal.html. 


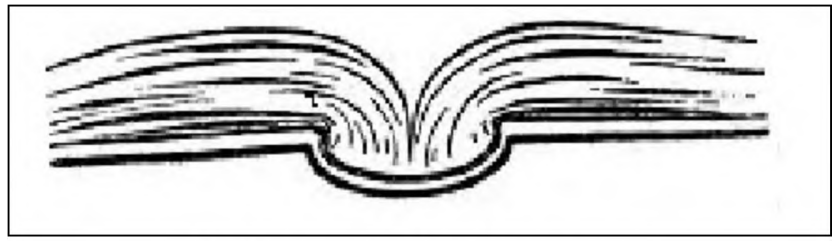

10. Oprawa z grzbietem zwartym

Sklejenie grzbietu wraz z materiałem pokryciowym, zwłaszcza z grubą skórą, powodowało jego usztywnienie i utrudniało otwieranie książki. Intensywne użytkowanie tomu powodowało $\mathrm{z}$ kolei powstawanie na grzbiecie pionowych zmarszczek, a czasem nawet odspajanie skóry od grzbietu. By temu przeciwdziałać zreformowano technikę oprawiania odseparowując grzbiet okładki od grzbietu bloku książki. Na grzbiet bloku książki naklejano skrawek papieru, który izolował klej, drugim paskiem, sklejonym z kilku warstw makulatury, usztywniano grzbietową partię skórzanej oklejki. Jednocześnie zaniechano uwypuklania zwięzów (zastosowano szycie na sznurki wpuszczone w nacięte w grzbiecie rowki). Oprawa z wolnym grzbietem, oddzielonym od bloku książki, zwana jest także oprawą z grzbietem odpadającym.

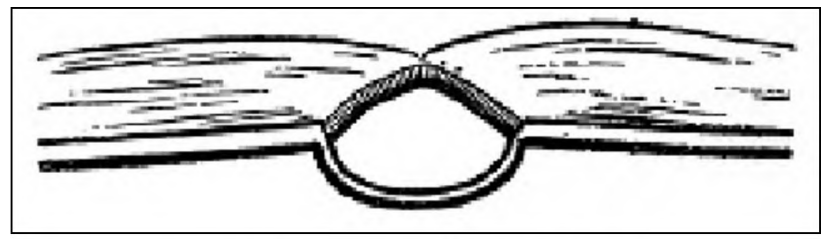

11. Oprawa z grzbietem wolnym

Zarówno w oprawie organicznej, jak i w oprawie z odpadającym grzbietem okładziny przysunięte są do samego grzbietu i mieszczą się w zagłębieniu uzyskanym dzięki zaoporkowaniu grzbietu. Sznurki zwięzów wychodzą na wierzch tektur i w przegubie tworzą lekkie uwypuklenie, wyczuwalne nawet przez oklejkę.

W połowie XIX wieku upowszechniła się nowa konstrukcja oprawy, tzw. bradel. Jej wynalazcą był Alexis-Pierre Bradel, francuski introligator czynny w XVIII wieku. Swe uproszczone oprawy z okładką wykonaną $\mathrm{z}$ jednego kawałka cienkiej tektury, przełamanej $\mathrm{w}$ miejscach, gdzie wypada grzbiet, a następnie oklejonej papierem lub płótnem traktował jako tanie oprawy tymczasowe lub też oprawy drobnych druków. Z czasem okładkę zaczęto konstruować z 3 odrębnych użytków: 
dwóch tekturowych okładzin oraz kartonowego paska usztywniającego grzbiet.

Istotą zmiany wprowadzonej przez tę technikę (zwaną oprawą zawieszaną lub zasadzaną) było przeniesienie miejsca zamocowania końcówek sznurków: $\mathrm{z}$ wierzchu tektur okładzinowych na ich stronę wewnętrzną. Konstrukcja taka wymagała odsunięcia okładek od grzbietu na ok. 3-4 mm, w przeciwnym razie naprężenia utrudniały otwieranie, i groziły pęknięciem przegubu. Pomiędzy okładką a grzbietem powstał odstęp, zwany odsadką lub wolnym przegubem (w przeciwieństwie do poprzedniego, zwanego przegubem zwartym). Połączenie bloku z okładkami przez końce zwięzów często uzupełniano o scyzurę - pasek płótna o szerokości kilku centymetrów, przymocowany do wyklejki. Montaż końcówek sznurków (wąsów) następował w tym wypadku najpierw do scyzury, a następnie, już razem z nią, do tekturek.

Kartonowe usztywnienie grzbietu (grzbietówkę) w oprawie zasadzanej naklejano na oklejkę. Z czasem nastąpiła modyfikacja: grzbietówkę naklejano na szerszy pasek papieru, przykładano do grzbietu książki a następnie przyklejano do przedniej i tylniej scyzury. Ten typ oprawy nazwano „łamanym grzbietem” (gebrochene Rücken). W następnej kolejności przyklejano na wierzch tekturki okładkowe. Czasem scyzurę wraz z paskiem papieru od grzbietówki, wklejano w środek okładzin, pomiędzy sklejone dwie cienkie tekturki. Oprawa taka była szczególnie estetyczna, gdyż wszystkie zgrubienia elementów konstrukcyjnych kryły się we wnętrzu okładek.

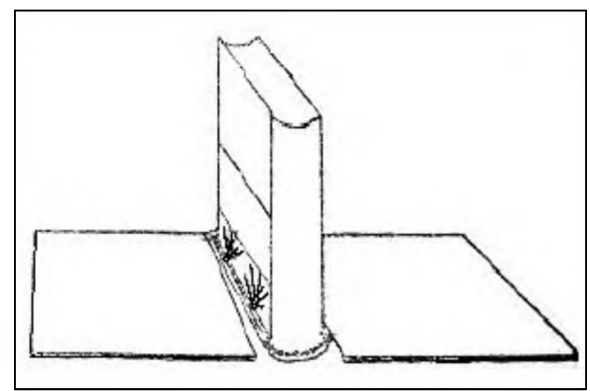

12. Konstrukcja oprawy zawieszanej (Bradel)

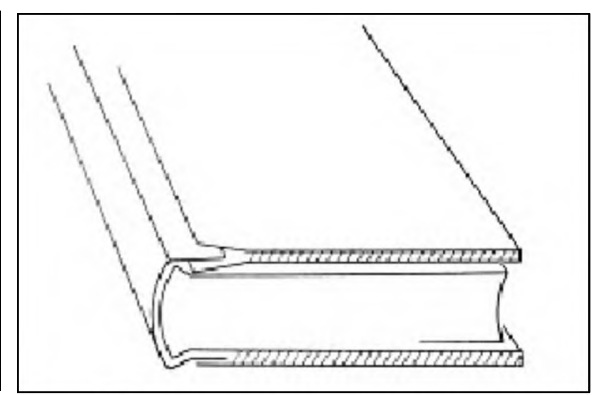

13. Oprawa z lamanym grzbietem

Wszystkie omówione dotąd rodzaje opraw twardych zwane bywają oprawami właściwymi lub też oprawami wykonywanymi na bloku. W drugiej połowie XIX wieku powstała nowa technologia, w której 
okładkę sporządzano osobno, następnie ją dekorowano i dopiero w końcowym etapie przyklejano do bloku książki. Metoda ta nazywana jest oprawą wklejaną, teczkową, a czasem, dość lekceważąco, kartonażem. Około roku 1870 technologia ta została zaadaptowana do rozwijającej się wówczas oprawy przemysłowej.

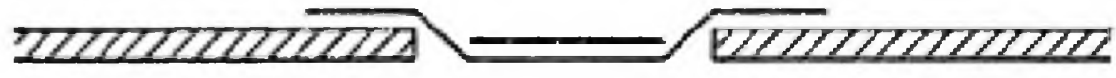

14. Przekrój okładki w oprawie wklejanej

W oprawie wklejanej połączenie następuje w drodze przyklejenia wyklejek wraz z elementami wzmacniającymi (scyzurą bądź skrzydełkami merli znajdującej się na grzbiecie) do wewnętrznej strony okładek. W przypadku cięższych tomów może nastąpić za pośrednictwem dodatkowego elementu, tzw. woreczka, zwanego też zwijką. Jest to papierowy rulonik wielkości grzbietu książki, przyklejony jedną powierzchnią do grzbietu bloku, a drugą do grzbietu okładki.

Przez długi czas obie techniki funkcjonowały równolegle: oprawa wklejana używana była dla opraw nakładowych wykonywanych sposobem fabrycznym, zaś oprawa „na bloku” - w pracach indywidualnych. Z czasem jednak nastąpiła ekspansja oprawy wklejanej, wyparła ona inne techniki i zepchnęła je w zapomnienie.

Rozwój oprawy à la rustica i wzbogacenie jej o tekturowe okładki wykształciło oprawę uproszczoną, zwaną też półtwardą lub „kartonem równociętym". Tekturowe okładki przyklejano do kart wyklejki, na grzbiet bloku książki naklejano pasek płótna (zachodził on częściowo na tektury), a całość oklejano po wierzchu papierem oklejkowym. Książkę obcinano już po jej oprawieniu, tak że okładki miały tę samą wielkość co trzon książki. Technologię tę stosowano głównie do druków drobnych, książek o mniejszej wartości, zarówno w oprawie nakładowej, jak i indywidualnej (zwłaszcza dla książek bibliotecznych).

\section{Okładka książki}

Okładka, zewnętrzna część książki, zabezpieczająca trzon, składa się z dwóch warstw: wewnętrznej - usztywniającej (okładzinówka), wykonanej z tektury, a w dawnych oprawach $-\mathrm{z}$ drewna, oraz zewnętrznej (oklejka), tj. materiału pokryciowego. Najpowszechniej stosowanym materiałem pokryciowym była przez wieki garbowana skóra zwierzęca. 
Rzadziej do sporządzania opraw używano skóry wyprawianej przez suszenie - czyli pergaminu; nadto tkanin, w tym jedwabiu i aksamitu, a do opraw tańszych płótna oraz papieru. Materiały te wykorzystywano niekiedy łącznie, w różnych kombinacjach. Zastosowany materiał pokryciowy jest cechą, według której dokonywana jest typologia opraw, stosowana w opisach książek (katalogi biblioteczne, antykwarskie, wystawowe).

Książkę pokrytą skórą zwie się oprawą skórzaną (skórkową, całoskórzaną bądź też oprawą w pełną skórę). Zależnie od gatunku skóry użytej do oprawy, mówi się o oprawach w safian, w marokin, w pergamin, w skórę cielęcą bądź świńską. Inne gatunki skór są trudniej rozpoznawalne po zewnętrznym wyglądzie.

Oprawa wykonana $\mathrm{z}$ tkaniny zwie się oprawą płócienną, przy czym wyróżnia się kosztowne materie (jedwab, atłas, aksamit), płótno lniane oraz apreturowane płótno introligatorskie, zwane też płótnem angielskim bądź kalikiem.

Nieuporządkowane natomiast pozostaje nazewnictwo oprawy oklejonej w całości papierem. Najwłaściwszym dla niej określeniem byłoby „oprawa twarda całopapierowa”, jednak nie jest ono stosowane, już raczej nazywa się ją opisowo „oprawą bibliofilską całopapierową" lub z niemiecka pappbandem. Czasem spotkać można określenie „karton” pochodzące zapewne od kartonażu („cartonnage”), czyli oprawy uproszczonej, jednak o tyle niesłuszne, że oprawa wykonana jest z tektury i papieru, nie zaś z kartonu.

Bibliofilskie oprawy papierowe często sporządzane są z artystycznie barwionego papieru, ich narożniki zaś oraz krańce grzbietu wzmocnione są skrawkami pergaminu bądź skóry. Nowoczesne oprawy wydawnicze często sporządzane są z lakierowanego papieru odrukowanego, dlatego też nazywa się je lakierowanymi.

Do pokrycia okładki często stosowano dwa rodzaje materiału. U źródeł takiego postępowania stała zapewne oszczędność. Z jednego płata skóry można było wyciąć oklejkę na jedną lub dwie książki. Pozostawały przy tym ścinki, które można było wykorzystać na małe książeczki lub właśnie na okładki w połączeniu z innym materiałem. Nawet w oprawach tańszych starano się, by „pracująca” część oprawy, czyli grzbiet i przegub były sporządzone z mocnego i trwałego materiału, dlatego część grzbietową książki oklejano skórą, resztę powierzchni okładzin powlekano papierem. Oprawę taką zwie się oprawą półskórkową, lub w skrócie półskórkiem (analogicznie: oprawa półpergaminowa lub półpergamin). W niektórych opisach spotkać się można z pedantycznym 
uszczegółowieniem nazewnictwa: półskórek to oprawa posiadająca skórzany grzbiet i narożniki, gdy zaś rogi nie zostały wzmocnione skórą, to oprawę taką nazywano ćwierćskórkową. Praktykowano także wzmacnianie narożników innym, tańszym materiałem, i tak w oprawie półskórkowej narożniki podklejano czasem płótnem. Obok uzasadnienia ekonomicznego działanie takie miało także uzasadnienie praktyczne; płócienne rogi były od skórkowych odporniejsze na ścieranie, na które narażone były okładki podczas wsuwania książki na biblioteczną półkę.

Na początku XIX wieku dość powszechne było takie sporządzanie oprawy półskórkowej, by zróżnicowanie materiałów było trudno dostrzegalne. Dla osiągnięcia tego celu stosowano skórę i papier podobnego koloru, a dodatkowo już po wykonaniu oprawy całą jej powierzchnię nakrapiano ciemnym barwnikiem (marmoryzowano).

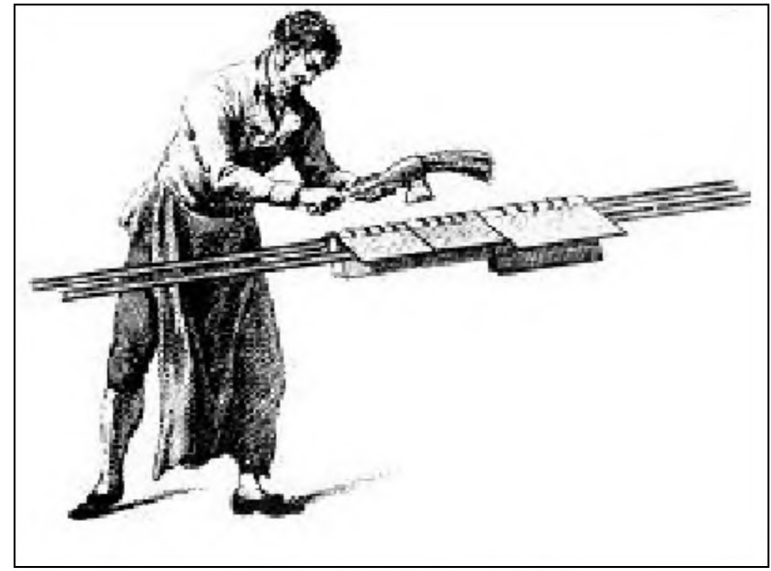

15. Nakrapianie okładek

Szczególnym rodzajem półskórka jest oprawa półsafianowa. Do naklejonej na grzbiecie barwnej skórki safianowej dopasowywano zbliżony kolorystycznie papier safianowy, tj. barwny papier glansowany, tłoczony w deseń podobny do skóry safianowej.

Uzupełnieniem zwykłych opraw półskórkowych w początkach wieku XIX był papier marmurkowy klajstrowy, w latach 30.-40. XIX wieku modny stał się papier marmurkowy karagenowy, zaś od lat 60 . - papier marmurkowy nakrapiany, tzw. Gustav-Marmor. W latach 70.-80. XIX wieku wielką popularność zyskała oprawa półskórkowa wykonywana z ciemnobrunatnej skóry o groszkowej fakturze, której okładki oklejano płótnem - kalikiem w zbliżonym kolorze i fakturze. 
Oprawę półskórkową, będącą pierwotnie wariantem oszczędnościowym, z czasem, przy ogólnej pauperyzacji, uznano za oprawę lepszego gatunku. Oprawy półskórkowe zaczęły otrzymywać bogate zdobienia, sporządzano także tzw. „szerokie półskórki”, w których powierzchnia pokryta skórą przeważała nad materiałem uzupełniającym. Skórzane przestrzenie na okładkach stały się także polem do dekoracji (tłoczeń, złoceń, aplikacji).

Przeciwieństwem „szerokiego półskórka” były rozmaite „oprawy milimetrowe” (Milimeterband), w których papier pokrywał niemal całą powierzchnię okładek, a skórzany płat grzbietowy widoczny był tylko na szerokości 1-2 mm od grzbietu. Jednocześnie stosowano tzw. „rożki kryte", a więc skórzane narożniki przykryte papierem tak, że skóra wystawała jedynie na samym rogu i na wewnętrznej stronie okładki. Innym wariantem oprawy, w której oszczędność materiałów szła w parze z wyrafinowaniem wykonania, była oprawa zwana po niemiecku Streifenband. Wąskie paski skóry lub pergaminu naklejano tylko na brzegach okładek: pionowo, tj. na grzbiecie i na pionowych krawędziach okładek lub też na poziomych krawędziach - tu pasek skóry przebiegał wzdłuż dolnej i górnej krawędzi obu okładek, stanowiąc zarazem wzmocnienie grzbietu i przegubów.

W Polsce rzadko stosowano technikę sporządzania okładek z 3 odrębnych części, tzw. aufgesetzte Deckeln (technika ta nie doczekała się polskiej nazwy). Zarówno grzbiet, jak i okładki mogły być oklejone skórą bądź płótnem, z tym że tekturki okładkowe najpierw oklejano materiałem pokryciowym, zawijając od razu krawędź przy grzbiecie, a dopiero później montowano je ze skórzanym paskiem grzbietowym (jego końce kryto pod spodem tekturek). Połączenie skórki z okładkami zasłaniano zawinięciami oklejki. Technika ta była szczególnie dogodna do wykonywania tłoczeń reliefowych, pozwalała także na wykonywanie opraw w dużych formatach z mniejszych płatów skóry. Dzięki niej uzyskiwano oprawy z różnych kolorów skór, lub też oprawy skórzano-płócienne, o tyle estetyczne, że zawinięty pod spód brzeg płótna nie groził strzępieniem.

Analogicznie do oprawy półskórkowej wygląda oprawa półpłócienna. Jej grzbiet wykonany jest z płótna, okładki zaś są oklejone papierem, z tym że czasami płótnem oklejano także rogi okładek. Oprawy półpłócienne sporządzano zarówno w pracach indywidualnych i bibliotecznych, jak i w oprawach nakładowych. W pierwszym przypadku na grzbiet często stosowano szare płótno lniane, okładki oklejano papierem 
marmurkowym. Półpłócienne oprawy wydawnicze zwane były potocznie oprawami książek szkolnych, jako że w przeważającej liczbie oprawę taką nadawano podręcznikom oraz literaturze popularno-naukowej i książkom dla dzieci. Na płóciennych grzbietach znajdował się tytuł wytłoczony farbą, tekturowe okładki powlekane były oklejką, przygotowaną specjalnie dla tej edycji. Zawierała ona tytul, a często także barwną ilustrację, związaną z treścią dzieła.

Jeszcze innym, szczególnym typem oprawy jest oprawa półmiękka, która tym różni się od zwykłej oprawy twardej, iż na okładki, zamiast tektury stosuje się karton. Dzięki temu okładka pozostaje elastyczna i pozwala się wyginać. W sporządzaniu oprawy półmiękkiej ze skóry nie naklejano materiału oklejkowego na okładkę, lecz tylko mocowano go w grzbiecie, a także przyklejano zawinięcia. Dzięki temu unikano usztywnienia okładki podczas sklejania materiałów. Oprawy półmiękkie miały niekiedy dodatkową warstwę miękkiego materiału (waty, miękkiej tkaniny) włożoną do wnętrza okładki, dzięki czemu były lekko wypukłe i miękkie jak poduszka ${ }^{25}$.

\section{Zdobienie okładek}

Funkcjonalna strona oprawy książki wymagała umieszczenia na niej tytulatury. Obok niej oprawy często posiadały, bogatsze lub skromniejsze, zdobienie. Oprawy indywidualne zdobiono na ogół ręcznym tłoczeniem, zwykłe dekorowanie książki ograniczało się do wyzłocenia tytułu na grzbiecie oraz wykonania typowych tłoczeń według standardowych, wyuczonych zasad. W przypadku bogatszego tłoczenia niezbędne było uprzednie sporządzenie projektu, rysowano go na kalce, oznaczając miejsce każdego tłoku, a następnie przez tę kalkę odciskano kolejno wszystkie tłoki. Odciski stawały się podtłokiem, miejscem gdzie należało nałożyć środek wiążący, a następnie złocić.

Oprawy seryjne dekorowano przy użyciu prasy do złocenia i specjalnych plakiet. Projekt dla oprawy nakładowej sporządzali czasem zawodowi artyści. Według tego rysunku następnie grawerowano lub trawiono specjalne matryce. Często wzór zdobniczy sporządzano z posiadanych w zakładzie tłoków uniwersalnych, które łączono w rozmaite kompozycje.

Okładki książek bywały zdobione rozmaitymi technikami; najbardziej znaną i cenioną jest złocenie. Złocenie prawdziwym złotem odbywa się przy użyciu środka gruntującego (albumina, klajster) i natłuszcza-

25 „Wypychanie” okładek stosowano niekiedy także w oprawach twardych. 
jącego oraz środka wiążącego - białka jaja kurzego. Przyłożony do właściwego miejsca płatek złota jest następnie wtłaczany rozgrzanym tłokiem metalowym, ręcznie lub przy użyciu prasy ${ }^{26}$.

Do złocenia, oprócz złota dobrego gatunku (Feingold, spolszczony na fajngult), stosowano także złoto z domieszkami innych metali (Zwischgold, cwiszgult), które miało tę wadę, iż po pewnym czasie czerniało, podobnie jak srebro, stosowane rzadko, z tego właśnie powodu. Nadto używano namiastki złota - szlagmetalu (stopu z przewagą miedzi), podobnie jak złoto, walcowanego na cienkie płatki. Na początku wieku XX weszła do użycia, wynaleziona przez Ernesta Oesera folia introligatorska, zawierająca oprócz drobin pigmentu bądź metalu, środek wiążący - kalafonię. Folie ułatwiły pracę złotnikom introligatorskim i w krótkim czasie wyparły płatkowe złoto, które bywa stosowane wyłącznie w pracach luksusowych.

Drugą, obok złocenia, tradycyjną metodą zdobienia okładek książkowych było wykonywanie wycisków ślepych ${ }^{27}$. Podobnie jak w procesie złocenia, na okładkach odciskano napisy, ornamenty i przedstawienia ilustracyjne; tłoczenia wykonywano ręcznie bądź przy użyciu prasy. Do ślepych wycisków na skórze, materiał nawilżano, tłoczenie powtarzano kilkakrotnie coraz cieplejszym tłokiem. Na skórach naturalnych (cielęcej, świńskiej) przy ostatnim tłoczeniu pocierano tłoki woskiem, co skutkowało przyciemnieniem wycisków.

Ślepe tłoczenie stało się techniką masowo stosowaną w tańszych oprawach nakładowych; większość płóciennych okładek popularnych edycji z przełomu XIX/XX wieku ma jakieś ślepe wyciski: liniowe, ornamentalne czy też liternicze.

Na płóciennych okładkach książek dokonywano także barwnych tłoczeń; wykonywano je przy użyciu farb drukarskich, później także barwnych folii. Do wielkiego mistrzostwa w barwnym tłoczeniu doszli introligatorzy w końcu XIX wieku, gdy modne były okładki zdobione malarsko, a tłoczenie na oprawach bliskie było wielobarwnemu drukowi.

${ }^{26}$ Możliwe jest także wykonywanie tłoczeń na zimno, z tym że skórzane podłoże musi być dogłębnie nawilżone, zaś docisk musi trwać dłużej, aż do całkowitego wyschnięcia wilgoci i białka. To takiego tłoczenia można było używać tłoków drewnianych, także drukarskich form drzeworytowych. Dowiódł tego w publicznej prezentacji w 2008 roku warszawski konserwator Jacek Tomaszewski, posiłkujący się opisem o podobnych próbach przeprowadzonych przez Anglików w latach 50. XX wieku, zob. B. Middleton, A History of English Craft..., s. 170-171. Częściej wykonywano ślepe tłoczenie na zimno przy użyciu plakiet. Pozostawiano wówczas okładkę (zwilżoną) wraz z plakietą dociśniętą w prasie na dłuższy czas (nawet na całą noc).

${ }^{27}$ Ślepe tłoczenie czasem błędnie nazywa się suchym tłokiem, które to określenie odnosi się do technik graficznych lub pieczęci odbijanych bez farby na papierze. 
Tłoczenie, czy to złote czy barwne czy też ślepe, mogło być wykonywane zarówno ręcznie jak i maszynowo: tłoczenia ręcznego dokonywano tłokami zaopatrzonymi w drewniane uchwyty, maszynowego zaś przy użyciu prasy: wówczas stosowano tłoki płaskie (plakiety, klisze bądź formy sklejone z pojedynczych małych ozdobników lub czcionek). Na oprawach indywidualnych wyciski wykonywano zarówno ręcznie, jak i przy użyciu prasy do złocenia, czasem też w jednej oprawie łączono oba te sposoby. Tłoczenie jednostkowe nawet przy użyciu prasy sami introligatorzy traktowali jako pracę ręczną, w której maszyna służy tylko swą siłą nacisku ${ }^{28}$. Za oprawę maszynową uznaje się oprawę nakładową, wykonywaną z jednolitej formy tłoczącej, którą odciskano taśmowo na wielu egzemplarzach okładek.

Na tańszych oprawach barwne tłoczenie bywało zastępowane przez naklejanie wielobarwnych ilustracji, zwykle litografii.

Barwne wzory na okładkach uzyskiwano nie tylko w drodze tłoczenia barwnego, lecz także stosując mozaikę skórkową. Z technologicznego punku widzenia mozaiki dzieli się na dwa rodzaje: mozaikę właściwą (intarsję), gdy skóra w pewnych miejscach została wycięta i zastąpiona wstawkami innego koloru, oraz nakładkę - gdy elementy barwne zostały przygotowane z cienko zszarfowanej (podciętej) skóry innego koloru i naklejone na wierzch. Brzegi barwnych wstawek (w obu technikach) były zwykle otaczane wyciskaną linią, złoconą lub ślepo tłoczoną.

Niektórzy introligatorzy, zamiast wstawiać elementy ze skóry innego koloru, wytypowane motywy podmalowywali ręcznie farbą, uzyskując podobny efekt. Zresztą, gdy chodzi o ręczne malowanie, było ono stosowane w oprawach ozdobnych: na oprawach z naturalnej skóry cielęcej nastrojowe sceny malowano monochromatycznie bejcą (technika wykorzystywana zwłaszcza na początku XIX wieku), na okładkach pergami-

${ }^{28}$ I. Kozłowski, Ztocenie toczone dawniej a dziś, „Polska Gazeta Introligatorska”, 1928, nr 1, s. 6: „Mówię tu o ręcznie oprawionych książkach, przy których wykonuje się ozdoby albo zupełnie na prasie do pozłacania, albo też częściowo tylko, w kombinacji ze złoceniem ręcznym. Do prac takich używa się zwykle puncyn już posiadanych, tak jak się używało dawniej stempli do złocenia ręcznego. Nie rzadko zdarza się też, że wykonujemy wyciski kombinowane, t.z., że mieszamy wyciski z prasy i wyciski ręczne na jednej płaszczyźnie. Tu szczególnie można, naturalnie przy projekcie bez zarzutu, mówić o pracy artystycznej. Więcej jeszcze, bo często się zdarza, że przyrządzenie i wyciskanie na prasie, wymaga często więcej pracy i stawia większe wymogi do dokładności wykonywującego, aniżeli złocenie ręczne. W takich wypadkach uznać nam trzeba pracę taką nie jako maszynową, lecz jako artystyczną pracę ręczną, bo choć nam prasa w takich wypadkach służy swą pomocą, to jednak nie z powodu, że chcemy racjonalnie pracować, a jedynie dlatego, że dźwignia prasy staje się dla nas olbrzymią nasadą stempla dla narzędzia, którego ręką samą wycisnąć nie mamy siły." 
nowych - czarnym tuszem. Na początku wieku XX oklejki barwiono batikiem.

Na przełomie XIX/XX wieku często stosowaną techniką zdobienia opraw książkowych był relief. W celu jego uzyskania na tekturę okładki naklejano elementy (najczęściej wycięte z tektury), mające się uwypuklić. Po obciągnięciu okładek oklejką, okładkę prasowano pod elastycznym dociskiem (warstwa bibuł, guma), a po wyschnięciu relief modelowano bądź to ręcznie, bądź też wytłokiem wklęsłej matrycy. Innym sposobem uzyskiwania precyzyjnych w rysunku reliefów było wytłaczanie samej oklejki podklejonej tylko cienką i miękką tekturką, przy użyciu matrycy z kontrmatrycą. Powstałą pod spodem pustą przestrzeń wypełniano (gipsem, kitem $z$ trocinami), a następnie podklejano drugą warstwą tektury. Podobnie wykonywano reliefy ręcznie modelowane: skórę wygniatano i modelowano od spodu uzyskując wypukłości, które podkreślano na wierzchniej stronie konturowym tłoczeniem lub nacinaniem. Wnętrze wypełniano masą plastyczną i tak przygotowaną oklejkę naklejano na okładkę.

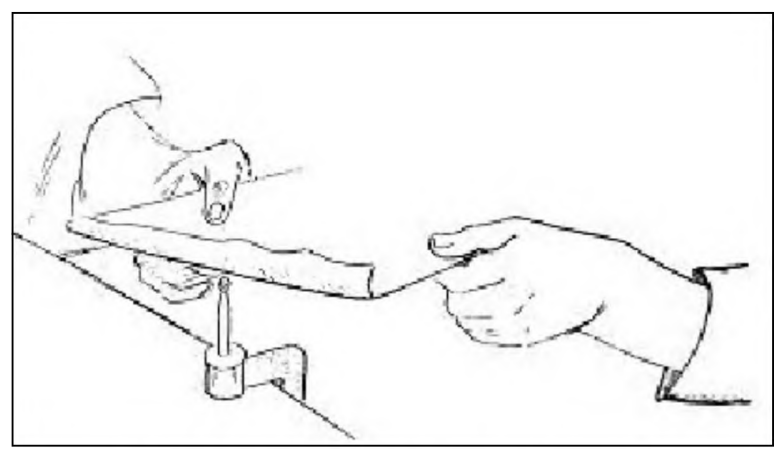

16. Ręczne modelowanie reliefu w skórze

Metalowe okucia i zapięcia stosowane w oprawach średniowiecznych i renesansowych powróciły do łask w końcu XIX wieku. W niewielkim stopniu pełniły funkcję ochronną, ich zadaniem było raczej podniesienie wystroju oprawy. Elementy metalowe rzadko używano w oprawach książek, natomiast zapinki występowały często na okładkach albumów fotograficznych, na księgach pamiątkowych lub tekach na dyplomy. Ponadto na oprawach mocowano metalowe grawerowane ozdoby - np. herby oraz napisy z pojedynczych mosiężnych liter.

Bardzo rzadko, i to raczej na oprawach amatorskich i artystycznych $\mathrm{XIX/XX}$. wieku, spotkać można inne techniki zdobnicze. Jedną z nich 
jest, zapomniany już właściwie, ledersznyt, stosowany także jako uzupełnienie w ręcznie modelowanych reliefach. Oprócz intarsji ze skóry innego koloru stosowano intarsje $\mathrm{z}$ innych materiałów: drewna, metalu, słomki itp. Okładki drewniane wykonywano technikami rzeźbiarskimi, snycerką, wycinanym piłką drewnianym ażurem itp. Na okładkach pojawiały się także hafty, wykonywane nie przez samych introligatorów, a raczej jako elementy przygotowane w ramach robótek kobiecych; w latach 20.-30. XIX wieku szczególne miejsce zajmował haft z ludzkich włosów.

\section{Procesy wykończeniowe}

Końcową czynnością w oprawianiu książki jest podklejenie wyklejek, a przez to zasłonięcie wszelkich nieestetycznych elementów konstrukcyjnych. W oprawach, które posiadają odsadkę pomiędzy grzbietem a okładziną ( $\mathrm{tj}$. oprawa zawieszana, oprawa $\mathrm{z}$ łamanym grzbietem i oprawa wklejana), przyklejenie obu wyklejek następuje na zamkniętej książce, pod naciskiem. W oprawach z przegubem zwartym, po podklejeniu wyklejek książka pozostaje otwarta, aż do wysuszenia. Wynika to z faktu, iż przegubowi niezbędny jest naddatek materiału pozwalający na swobodną pracę - w oprawie $\mathrm{z}$ odsadką ta fałdka znajduje się na wierzchu okładki, właśnie w odsadce, w oprawie zaś dosuwanej do grzbietu - naddatek materiału mieści się wewnątrz przegubu.

W oprawach luksusowych wykonanych techniką francuską, często spotykamy wyklejkę ze skórzanym falcem, tj. wklejonym w przegubie paseczkiem, sporządzonym z tej samej skóry, którą obciągnięto okładkę. Podwinięcia skóry, a także ów falc bywały również miejscem, w którym wykonywano dekoracyjne złocenia. W szczególnych przypadkach wyklejki sporządzano nie z papieru, lecz z kosztownych materiałów jak jedwab, pergamin, skóra; skórzane bądź jedwabne wyklejki bywały także polem do bogatych dekoracji. W takim wypadku mówi się o oprawie dublowanej czyli dublurze.

Ostatnią pracą wykonywaną przez introligatora jest kontrola oprawy i usunięcie ewentualnych mankamentów. Do prac wykończeniowych należało wygładzenie rozgrzanym żelazkiem (polerrajzą) ewentualnych skaz skóry oraz różnych elementów konstrukcyjnych, które nadmiernie uwypukliły się pod oklejką albo wyklejką.

Luksusowe oprawy niekiedy zaopatrywano w futerały. Stare książki rzadko posiadają futerały, co jak się wydaje jest w mniejszym stopniu wynikiem ich zniszczenia bądź zagubienia, niż małą popularnością tych 
elementów ochronnych. Większość zachowanych futerałów z początku XIX wieku miała inny kształt niż futerały dziś stosowane: były to pudełeczka, do których książkę wsuwano od góry. Niektóre z nich nie miały ochronnej ścianki górnej, inne złożone były z dwóch części: książkę wkładano w dolną część, a na nią wsuwano zamykającą przykrywkę. Futerały sporządzano z tektury i oklejano je zwykle barwnym papierem. Niektóre miały formę prostego pudełka, w innych występował wyprofilowany bok dopasowany do zaokrąglenia grzbietu. W drugiej połowie XIX wieku spopularyzował się futerał w formie stosowanej do dziś - pudełko z odkrytą ścianką grzbietową. Dla książek chronionych wykonywane są futerały kasetowe.

\section{Bibliografia:}

- Arct M. jr, Jak powstaje ksiażka, Warszawa 1929.

- Arnett J.A., Bibliopegia, or the Art of Bookbinding, in All its Branches, London 1835.

- Bonnardot A. , Essai sur l'art de restaurer les estampes et les livres, Paris 1846.

- Brade L., Winckler E., Das illustrierte Buchbinderbuch, Leipzig 1860.

- Czyżycki W., Introligatorstwo. Wskazówki techniczne, Warszawa 1948.

- Czyżycki W., Prace z papieru, kartonu, tektury. Introligatorstwo, Warszawa 1958.

- Devauchelle R., La reliure. Recherches historiques, techniques, et biographiques sur la reliure français, Paris 1995.

- Doležal J., Vazby knih, Praha 1987.

- de Haas H., De Beokbinder, Dordrecht 1806 (reed. 1984).

- Introligatorstwo domowe, oprac. M. Stefkowa, Warszawa (1932).

- Kuglin J., Poligrafia ksiażki, Wrocław 1968.

- Latoszyńska H., Oprawianie książek jako miła rozrywka, „Bluszcz”, 1931, nr 1.

- Lenart B., Dzisiejsza „oprawa” $i$ dobra oprawa, „Praca Ręczna w Szkole”, 1928, nr 1; w wydaniu samoistnym, Warszawa 1928.

- Lenormand L.S., Nouveau manuel complet de relieur dans toutes ses partes, Paris 1840.

- Lorentowiczowa E., Zdobnictwo skóry, „Nasz Dom. Tygodnik Mód i Powieści”, 1913, nr 3, 13, 14, 18, 21, 23, 24.

- Magdzik S., Introligatorstwo przemystowe, Warszawa 1988.

- Middleton B.C., A History of English Craft Bookbinding Technique, London 1978. 
- Osięgłowski J., Ochrona ksiażki bibliotecznej, Poznań 2003.

- Pietruczuk I., Godlewski H., Jędrych W., Technika i technologia introligatorstwa przemystowego, Warszawa 1985.

- Radomczyk M. (Mosiołek), Domowa nauka oprawiania ksiażek, Warszawa 1899; toż 1908, 1922.

- Rajewska W., Introligatorstwo w domu i w szkole, Cieszyn 1924.

- Semkowicz A., Introligatorstwo z krótkim zarysem historii zdobnictwa opraw, Kraków 1948.

- Semkowicz A., Oprawa ksiażek, Kraków 1926.

- Sowiński M., Nauczanie robót ręcznych, Część I: Oprawy, podręcznik ułożył i rysunkami objaśnił H. Policht, Kraków 1925; Część II: Roboty z papieru, kartonu, tektury i pomoce naukowe, Kraków 1930.

- Wspótczesne polskie introligatorstwo i papiernictwo. Mały stownik encyklopedyczny, Wrocław 1986.

- Zjawiński Z., Introligatorstwo, Warszawa 1966 i toż 1967.

\section{Summary}

Bookbinding in the $19^{\text {th }}$ and the First Half of the $20^{\text {th }}$ Century: Binding Technique and the Structural Elements of the Book

The external appearance of a book depends on a number of factors, one of which is the method according to which the bookbinding is executed. Consequently, many other features of the book are related to the applied technology of the bookbinding. The article deals with various methods of bookbinding, which result in differences in the looks and the making of many of the elements of the final product: endpapers, page-linking techniques, decorating of page exteriors, methods of constructing the binding, i.e. the fixing together of the body of the book with the covers, and finally the construction and the decoration of the covers themselves. The author concentrates on the bookbinding techniques of the $19^{\text {th }}$ and early $20^{\text {th }}$ century, dealing both with traditional handicraft, which manifests little change since the Renaissance period, as well as on the occurring transformation, which consisted in gradual mechanisation of the bookbinding process, and on the arrival of serial binding of larger quantities of books, or even of whole issues. 